\title{
PERANCANGAN ALAT REFLEXI YANG ERGONOMIS DENGAN BATU GIOK
}

\author{
ST.Salammia l.A 1), Sanny Anjarsari 2), Sri Indriani ${ }^{3)}$ \\ ${ }^{1,2,3)}$ Prodi Teknik Industri, Fakultas Teknologi Industri, Institut Teknologi Nasional Malang
}

\begin{abstract}
Abstrak, Perancangan alat Reflexi yang beredar di pasaran untuk menunjang kesehatan belum dirancang berdasarkan standard ergonomis, Salah satu diantaranya adalah ceragem, yaitu salah satu teknik pengobatan efektif yang memaduhkan teknologi canggih dunia kedokteran dengan pengobatan tradisional warisan leluhur. Ceragem merupakan sebutan alat kesehatan yang menggunakan teknologi sinar infra merah dipadukan dengan batu giok dalam balutan mesin berteknologi canggih. Terdapat empat prinsip utama pengobatan ceragem yakni urut, knop, Infra merah jauh dan Chiroparactic (tulang belakang) menjadi langkah proses penyembuhan. Ukuran yang tidak tepat pada syaraf yang diterapi disebabkan ukuran Tubuh Bangsa Indonesia terutama tinggi badan tidak sesuai dengan ukuran alat reflexi sehingga titik-titik syaraf yang direflexi tidak tepat seperti yang terlihat perbedaan tinggi badan menurut Program Mannequin Pro antara eropa dan Asia.Tinggi Tubuh untuk menentukan panjang tempat tidur terapi $=170 \mathrm{~cm}$, Panjang Tulang Belakang Untuk menentukan perletakkan dari batu giok yang diletakkan disekitar bagian tulang belakang $=72 \mathrm{~cm}$, Lebar Bahu untuk menentukan lebar tempat tidur terapi $=52 \mathrm{~cm}$ Panjang Popliteal untuk menentukan perletakkan dari batu giok betis $=45$ $\mathrm{cm}$.Panjang Paha untuk menentukan peletakan dari batu giok bagian paha $=55 \mathrm{~cm}$,Panjang Perut untuk menentukan peletakan batu giok bagian perut $=26 \mathrm{~cm}$, Lebar Pinggul untuk menentukan peletakan batu giok bagian pinggang dan pinggul $=41 \mathrm{~cm}$.
\end{abstract}

Kata Kunci : Perancangan, Alat Reflexi, Ergonomis, Standard, Ceragem, Infra Merah, Batu Giok

\section{PENDAHULUAN}

Berdasarkan hasil survey di beberapa tempat pelayanan Jasa kesehatan di Kota Malang, terdapat alat-alat elektronik yang berfungsi sebagai alat reflexi untuk syaraf yang tidak berfungsi secara efektif sehingga fungsi dari alat tersebut tidak mencapai tujuan utama dari alat tersebut. Salah satu alat reflexi tersebut adalah reflexi batu giok. Alat tersebut dirancang dengan pedoman ukuran antropometri yaitu dengan desain ukuran tubuh orang Eropa sesuai asal produk tersebut.

Antropometri menurut ukuran tubuh manusia yang telah dituangkan dalam program Mannequin Pro terdiri dari beberapa ukuran seperti untuk benua Asia. Bangsa Indonesia sudah masuk dalam kelompok ukuran Asia Tenggara yang dikategorikan postur tubuh hampir sama, salah satunya adalah Antropometri untuk Bangsa Indonesia, maka dengan hasil survey yang dilakukan di Kota Malang pada tempat-tempat pelayanan Kesehatan Reflexi terlihat bahwa alat tersebut perlu didesain ulang yang akan disesuaikan dengan Antropometri orang Indonesia yaitu kelompok Asia Tenggara.

Ukuran yang tidak tepat pada syaraf yang diterapi disebabkan ukuran Tubuh Bangsa Indonesia terutama tinggi badan tidak sesuai dengan ukuran alat reflexi sehingga titik-titik syaraf yang direflexi tidak tepat seperti yang terlihat perbedaan tinggi badan menurut Program Mannequin Pro

Tabel 1: Ukuran Tubuh Manusia Asia dan Eropa

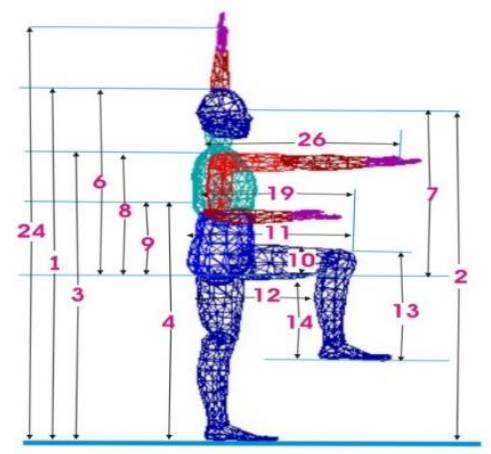

Gambar 1; Struktur pengukuran Antropometri 
1. Aplikasi Data Anthropometri Dalam Perancangan Produk / Fasilitas Kerja

Terdapat tiga prinsip dalam pemakaian data anthropometri, yaitu:

a. Perancangan berdasakan individu ekstrim.

Prinsip ini digunakan apabila kita mengharapkan agar fasilitas yang dirancang tersebut dapat dipakai dengan enak dan nyaman oleh sebagian besar orang-orang yang akan memakainya (biasanya minimal oleh $95 \%$ pemakai).

b.Perancangan fasilitas yang bisa disesuaikan Prinsip ini digunakan untuk merancang suatu fasilitas agar fasilitas tersebut bisa menampung atau bisa dipakai dengan enak dan nyaman oleh semua orang yang mungkin memerlukannya.

c.Perancangan fasilitas berdasarkan harga ratarata pemakainya

Prinsip ini hanya digunakan apabila perancangan berdasarkan harga ekstrim tidak mungkin dilaksanakan dan tidak layak jika kita menggunakan prinsip perancangan fasilitas yang bisa disesuaikan.

\section{Analisa Statistik}

\section{a.Rata-rata Hitung}

Rata-rata hitung untuk data kuantitatif yang terdapat dalam sebuah sampel dihitung dengan jalan membagi jumlah nilai data oleh banyak data (Sudjana, 1975 : hal 66) atau lebih sederhana lagi ditulis:

\begin{tabular}{|c|l|c|c|c|}
\hline \multirow{2}{*}{ NO. } & \multirow{2}{*}{$\begin{array}{c}\text { JENIS } \\
\text { UKURAN }\end{array}$} & \multicolumn{2}{|c|}{$\begin{array}{c}\text { ANTROPHOMETRI } \\
\text { (satuan cm) }\end{array}$} & $\begin{array}{c}\text { SELISIH } \\
\text { (satuan } \\
\text { TEIA }\end{array}$ \\
\hline 1. & Tinggi tubuh & 177 & 189 & 12 \\
\hline 2. & Lebar bahu & 47 & 51 & 4 \\
\hline 3. & $\begin{array}{l}\text { Lebar } \\
\text { pinggul }\end{array}$ & 37 & 40,5 & 3,5 \\
\hline 4. & $\begin{array}{l}\text { Jarak } \\
\text { pinggul ke } \\
\text { lutut }\end{array}$ & 49,5 & 55 & 55,5 \\
\hline 5. & $\begin{array}{l}\text { Panjang } \\
\text { popliteal }\end{array}$ & 44,5 & 49 & 4,5 \\
\hline
\end{tabular}

$$
\overline{\mathrm{x}}=\frac{\sum \mathrm{X}_{\mathrm{i}}}{\mathrm{n}}
$$

Dimana : $\overline{\mathrm{x}}=$ Rata-rata hitung

$$
\sum \mathrm{X}_{i}=
$$

Total hitung sampel

$\mathrm{n}$ = banyaknya (jumlah) sampel / data

\section{b.Simpangan Baku atau Deviasi Standard}

Standard deviasi adalah suatu statistik yang digunakan untuk menggambarkan variabilitas dalam suatu distribusi maupun variabilitas beberapa distribusi. Standard deviasi secara matematik dibatasi sebagai akar dari jumlah deviasi kuadrat dibagi banyaknya individu dalam distribusi (Sutrisno Hadi 1989 : hal 90).

$$
\begin{aligned}
& S D=\sqrt{\frac{\sum X^{2}}{N}-\left[\frac{\sum X}{N}\right]^{2}} \\
& \text { Disederhanakan menjadi : } \\
& S D=\sqrt{\frac{\sum X^{2}}{N}-\frac{\left(\sum X\right)^{2}}{N^{2}}} \\
& S D=\sqrt{\frac{N \sum X^{2}}{N^{2}}-\frac{\left(\sum X\right)^{2}}{N^{2}}} \\
& S D=\sqrt{\frac{N\left(\sum X^{2}\right)-\left(\sum X\right)^{2}}{N(N)}}
\end{aligned}
$$

Dimana :

$$
\begin{array}{ll}
\mathrm{SD} & =\text { Standard Deviasi } \\
\mathrm{N} & =\text { Jumlah Pengamatan } \\
\mathrm{X} & =\text { Nilai Data Pengamatan }
\end{array}
$$

\section{c.Uji Keseragaman Data}

Peta kontrol (control chart) adalah suatu alat yang tepat guna dalam mengetest keseragaman data yang dipoeroleh dari hasil pengamatan. Dalam peta kontrol terdapat batas kontrol atas (BKA) dan batas kontrol bawah (BKB). Untuk mencari BKA dan BKB dicari dengan formulasi sebagai berikut :

$$
\begin{aligned}
& B K A=\bar{x}+k . S D \\
& B K B=\bar{x}-k . S D
\end{aligned}
$$

Dimana :

$$
\begin{aligned}
\mathrm{BKA} & =\text { Batas Kontrol Atas } \\
\mathrm{BKB} & =\text { Batas Kontrol Bawah } \\
\bar{x} & =\text { Harga rata-rata } \\
\mathrm{k} & =\text { Tingkat kepercayaan } \\
\mathrm{SD} & =\text { Standard Deviasi }
\end{aligned}
$$

Tingkat kepercayaan 95\% $\quad \mathrm{k}=2$

\section{d.Uji Kecukupan Data}

Untuk menetapkan berapa jumlah observasi yang seharusnya dibuat (N') maka disini harus diputuskan terlebih dahulu berapa tingkat kepercayaan (convidence level) dan derajat ketelitian (degree of accuracy) untuk pengukuran kerja ini. Didalam aktivitas pengukuran kerja biasanya akan diambil $95 \%$ convidence level dan 5\% degree of acccuracy. Hal ini bahwa sekurang-kurangnya 95\% dari 
100 harga rata-rata dari waktu yang dicatat/diukur untuk suatu elemen kerja akan memiliki penyimpangan tidak lebih dari 5\% ( Sritomo, W 1995: hal 184 ). Formula untuk uji kecukupan data dengan tingkat $95 \%$ convidence level dan $5 \%$ degree of accuracy adalah

Dimana :

$$
N^{\prime}=\left[\frac{40 \sqrt{N\left(\sum x^{2}\right)-\left(\sum x\right)^{2}}}{\left(\sum x\right)}\right]^{2}
$$

$N^{\prime}=$ jumlah pengamatan yang harus dilakukan $\mathrm{N}=$ jumlah data pengamatan yang telah dilakukan

$x=$ nilai data pengamatan

Jika N'> N Data pengamatan tidak cukup

Jika N'< N Data pengamatan cukup

Sedangkan uji kecukupan data yang dipakai untuk mengolah data anthropometri tubuh manusia ( Eko Nurmianto 2003 : hal 77 ) adalah sebagai berikut dengan mensubtitusikan rumus - rumus dibawah ini :

$$
\mathrm{S}_{\mathrm{x}}=\frac{\sigma_{x}}{\sqrt{N}}
$$

Dimana :

$\mathrm{SD}=$ Standart Deviasi

$\mathrm{N}=$ Ukuran sampel yang nilai rata-ratanya ditentukan.

Untuk 95\% tingkat kepercayaan ( Confidence Level ), nilai rata-rata sebenarnya adalah

$$
x \pm 1,96 S_{x}
$$

Apabila nilai rata-rata yang akan diukur adalah dengan derajat ketelitian 5\%, maka :

$$
=1,96 \mathrm{~S}_{\mathrm{x}}=\frac{5}{100} \bar{X}
$$

$=$ Subtitusi dengan rumus diatas menjadi

$$
\begin{gathered}
1,96 \mathrm{~S}_{\mathrm{x}}=\frac{5}{100} \bar{X} \\
1,96 \frac{S D}{\sqrt{N}}=\frac{\overline{5 X}}{100} \\
5 \bar{X} \sqrt{N}=(1,96)(100) \mathrm{SD} \\
5 \sqrt{N}=\frac{196 S D}{\bar{X}} \\
\mathrm{~N}=1536,64\left(\frac{S D}{\bar{X}}\right)^{2}
\end{gathered}
$$

$\operatorname{Dimana} \frac{S D}{\bar{X}}=\mathrm{v} \longrightarrow$

$$
\mathrm{v}=\text { koefisien variansi }
$$

Berikut ini adalah daftar nilai koefisien variansi berbagai macam dimensi tubuh manusia.

Formula untuk menghitung jumlah data yang seharusnya dilakukan adalah :

$\mathrm{N}^{\prime}=\mathrm{S}_{\mathrm{x}} \mathrm{N}$

Dimana $\mathrm{S}_{\mathrm{x}}=$ Standard Error

Standard error yang dipakai (Eko Nurmianto 1998 : hal 78) adalah :

- Untuk 10 dan 90 persentil dipakai $1,7 \mathrm{~S}_{\mathrm{x}}$

- Untuk 05 dan 95 persentil dipakai 2,1 $\mathrm{S}_{\mathrm{x}}$

- Untuk 01 dan 99 persentil dipakai 3,75 $\mathrm{S}_{\mathrm{x}}$

\section{e.Distribusi Frekuensi}

Untuk membuat distribusi frekuensi dengan panjang kelas yang sama (Sudjana, 1975, : Hal 47), dilakukan cara sebagai berikut

Tentukan rentang ( $\mathrm{R}$ ), dimana $\mathrm{R}=$ data terbesar - data terkecil

Tentukan banyak kelas interval ( $\mathrm{K}$ ) yang diperlukan. Banyak kelas sering diambil paling sedikit 5 dan paling banyak 15, dipilih menurut kebutuhan.

Cara lain adalah dengan menggunakan aturan Sturges yaitu:

$$
\mathrm{K}=1+3,3 \log \mathrm{N}
$$

Dimana : $\mathrm{K}=$ Banyak Kelas

$$
\mathrm{N}=\text { Banyaknya Data }
$$

Tentukan panjang kelas interval ( p)

$$
\mathrm{p}=\frac{\operatorname{Re} n \tan g}{\text { BanyakKelas }}=\frac{R}{K}
$$

Pilih ujung bawah interval pertama

\section{f.Persentil}

Persentil adalah suatu nilai yang menyatakan bahwa persentase tertentu dari sekelompok orang yang dimensinya sama dengan atau lebih rendah dari nilai tersebut (Eko Nurmianto, 1998 : hal 51). 
Tabel 2 : Persentil

\begin{tabular}{|l|c|}
\hline \multicolumn{1}{|c|}{ MACAM DIMENSI } & F. Var., v . (\%) \\
\hline $\begin{array}{l}\text { Anggota Tubuh Memanjang } \\
\text { (tinggi badan, tinggi duduk, } \\
\text { tinggi mata) }\end{array}$ & 3,7 \\
\hline $\begin{array}{l}\text { Anggota Tubuh Memanjang ( } \\
\text { yang lebih pendek ) }\end{array}$ & 4,6 \\
\hline $\begin{array}{l}\text { Lebar Tubuh (lebar pinggul, } \\
\text { lebar bahu) }\end{array}$ & 5,9 \\
\hline $\begin{array}{l}\text { Tebal Tubuh (tebal dada, tebal } \\
\text { perut) }\end{array}$ & 8,8 \\
\hline $\begin{array}{l}\text { Ukuran Kepala (panjang, lebar } \\
\text { kepala) }\end{array}$ & 3,5 \\
\hline
\end{tabular}

Untuk data anthropometri, besarnya nilai percentil dapat ditentukan dari tabel probabilitas distribusi normal. Distribusi normal ditandai dengan adanya nilai mean (rata-rata) dan SD (standard deviasi).

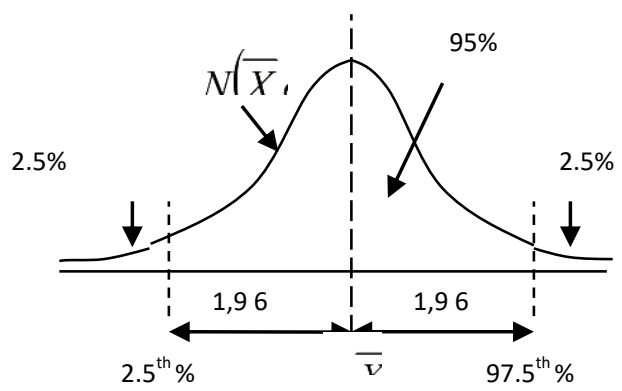

Tabel 3 : Formula untuk menghitung nilai persentil data anthropometri sebagai berikut

\begin{tabular}{|c|c|}
\hline PERCENTILE & CALCULATION \\
\hline $1 \mathrm{st}$ & $\bar{X}-2.325 \sigma_{x}$ \\
\hline $2.5 \mathrm{st}$ & $\bar{X}-1.960 \sigma_{x}$ \\
\hline $5 \mathrm{st}$ & $\bar{X}-1.645 \sigma_{x}$ \\
\hline $10 \mathrm{st}$ & $\bar{X}-1.280 \sigma_{x}$ \\
\hline $50 \mathrm{st}$ & $\bar{X}$ \\
\hline $90 \mathrm{st}$ & $\bar{X}+1.280 \sigma_{x}$ \\
\hline $95 \mathrm{st}$ & $\bar{X}+1.645 \sigma_{x}$ \\
\hline $97.5 \mathrm{st}$ & $\bar{X}+1.960 \sigma_{x}$ \\
\hline $99 \mathrm{st}$ & $\bar{X}+2.325 \sigma_{x}$ \\
\hline
\end{tabular}

\section{g.Terapi Batu Giok (CERAGEM)}

Pesatnya perkembangan dunia kesehatan membuat kita dapat memilih alternatif dalam hal pengobatan yang tidak melulu menggunakan pengobatan modern. Salah satu diantaranya adalah ceragem, salah satu teknik pengobatan efektif yang memadukan teknologi canggih dunia Kedokteran dengan pengobatan tradisional warisan leluhur.

Ceragem merupakan opsi alternatif yang menjembatani antara teknologi barat dengan warisan pengobatan warisan leluhur. Kombinasi dari dua dunia pengobatan itu diyakini menimbulkan sinergi yang ampuh membantu kesembuhan. Berasal dari negeri gingseng, Korea, Ceragem kini menjadi solusi alternatif masyarakat Indonesia yang kerap bingung memilih cara menuju sembuh.

Ceragem merupakan sebutan alat kesehatan yang menggunakan teknologi sinar infra merah yang dipadukan dengan batu giok dalam balutan mesin berteknologi canggih. Terdapat empat prinsip utama pengobatan ceragem yakni urut, knop, Infra merah jauh dan Chiroparactic (tulang belakang) menjadi langkah proses penyembuhan.

Prinsip urut pada tubuh manusia diyakini masyarakat timur memiliki aliran chi. Apabila terserang penyakit maka aliran chi menjadi terhambat dan akibatnya metabolisme tubuh tidak berjalan normal lalu tubuh pun sakit. Dengan batu giok yang berjumlah 9 buah pada ceragem akan memberikan tekanan pada tubuh pada 12 titik di daerah tulang belakang dan 3 titik pada perut, dengan begitu aliran darah akan menjadi lancar.

Sedangkan prinsip kop, diyakini mampu memberikan rangsangan, mengaktifkan fungsi sel, membantu memproduksi sel, membersihkan pembuluh darah hingga malancarkan peredaran darah, memperbaiki syaraf dan menaktifkan metabolime hingga tubuh anti bodi pun meningkat.

Prinsip ketiga, pemberian sinar infra merah. Menurut kepercayaan masyarakat Timur, sinar infra merah merupakan sinar kehidupan yang diyakini mampu menembus ke dalam tubuh dengan mengeluarkan rasa panas dan selanjutnya mendeteksi penyakit ditubuh.

Sinar infra merah yang berpadu ketika batu giok memberikan tekanan pada titik-titik pada tubuh akan sumber penyakit. Hasil deteksi terlihat pada kulit yang menjadi kemerahan karena peredaran darah ditubuh tidak lancar.

Prinsip terakhir adalah Chiropractic atau tulang belakang. Ceragem, merupakan pengobatan yang diyakini bahwa sumber berbagai penyakit berasal dari tulang belakang. 
Tulang punggung, memiliki susunan syaraf yang vital bagi tubuh. Ketika tubuh mengalami gangguan maka diyakini permasalahan bisa berasal dari tulang belakang.

Seluruh tahapan prinsip dilaksanakan dalam waktu 30 menit. Dibagi menjadi dua sesi, pertama sesi bagian tulang belakang serta pinggul dan kedua, sesi badan. 13 titik pada tulang belakang dan 3 titik pada perut diberi waktu penekanan oleh giok dan penyinaran sinar infra merah jauh selama dua menit. Pemberian sinar infra merah jauh tidak dilakukan secara terus menerus namun berotasi.

Esensi pengobatan Ceragem, pada dasarnya tercantum dalam tiga poin yakni menyembuhkan, mendeteksi dan merawat. Jika dalam dunia kedokteran dikenal dengan istilah pantangan.

Manfaat utama pengobatan Ceragem mampu menyembuhkan beragam penyakit. Seperti gangguan ginjal, kencing manis, sakit jantung, asam urat darah tinggi, gangguan labung, stoke dan lain-lain. Selain itu, penyembuhan melalui pengobatan ceragem tidak menimbulkan efek samping. Sekalipun terjadi reaksi, hal itu merupakan kerja penyinaran sinar infra merah jauh yang menjadi bagian prosesi dalam tubuh untuk memperbaiki diri.

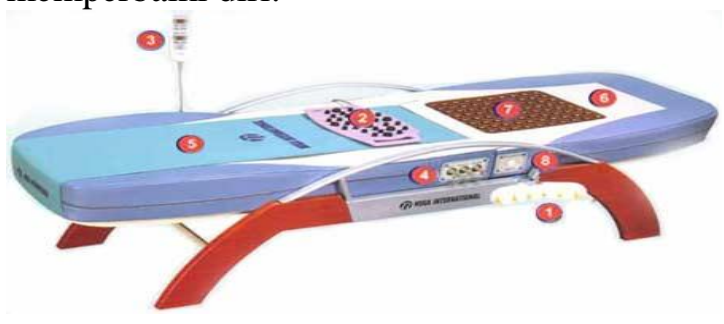

\section{Gambar 2 :Bagian-bagian pada Alat Terapi} Batu Giok

Keterangan Bagian-bagian pada Alat Terapi Batu Giok

a.Proyektor Bola Lima (Five Ball Projector) Internal Proyektor Proyektor bola 5 hadir dengan bentuk muka melengkung menyerupai gagang telpon dan dihubungkan dengan kabel ke panel konektor yang dapat mengurangi hilangnya panas dan hilangnya sinar infra merah jauh dan dapat dengan mudah digunakanan disetiap titik bagian tubuh manusia yang mengalami sakit.

b.Alas Bantal Frekuensi Rendah Pengontrol Lemak (Low Frequency Pad for Abdominal
Fat

Control).

LFP dihubungkan dengan kabel ke panel konektor, dapat digunakan tepat diatas perut atau daerah lain pada tubuh yang berkelebihan lemak sehingga mempercepat berkurangnya lemak serta memperbaiki fungsi organ tubuh yang mengalami kelainan. c.Remote Kontrol (Remote Control) Tombol-tombol yang memudahkan kita memilih tombol yang tepat sesuai dengan keinginan kita. Ukuran remote kontrol yang memudahkan kita untuk melihatnya. Rak remote kontrol yang memudahkan kita untuk mencapainya dan tepat penyimpanan sementara remote kontrol.

d.Panel-Penghubung (Connector-Panel)

Panel penghubung yang digunakan oleh proyektor bola lima, LFP, dan remote kontrol pusat penghubung yang terpisah memberikan penggunaan yang sesuai, oleh karena itu dua orang yang berbeda dapat mennggunakannya secara bersamaan.

f.Internal,Proyektor,Internal proyektor bergerak secara halus sepanjang garis tulang belakang, bersamaan dengan itu internal proyektor juga memberikan tekanan jari, urutan tangan dan pemanasan pada otot-otot tulang belakang.

g.Pengatur Tinggi (Hight Control Feature) Sandaran dapat diatur menurut sudut yang diinginkan 10, 20 atau 30 derajat menyesuaikan bentuk fisik dan karakteristik tubuh.

h.Keramik Tourmanium Penghantar Panas (Tourmamnium Ceramic-Heater-Mat) Ini sangat istimewa, matras pembantu perpaduan keramik Tourmaline digunakan untuk meningkatkan sentuhan panas sebaik keuntungan yang diberikan oleh generasi sinar infra merah jauh yang menyehatkan. i.Panel Suhu (Temperature Panel) Pengatur suhu sesuai yang diinginkan dan dengan mudah menyesuaikan kondisis fisik atau karakteristik tubuh. Penggunaan Low Frequency Pad (LFP) untuk pengontrol berat tubuh dan mengembalikan kesehatan tubuh anda dan sudut,keindahan. Mengembalikan Kepercayaan diri anda dengan $L F$ Weight Control Pad (Matras pengontrol Berat)

- Membuat Diet

- Menghilangkan lemak

- Mengembalikan kekuatan kulit

- Menghilangkan rasa sakit pada pundak, punggung dan pinggang 
- Meredakan mati rasa pada kaki dan tangan,

- Membantu menghilangkan rasa lelah dan memperlancar sirkulasi darah

- Menyembuhkan sakit otot dan sakit saraf

Tujuan dari Penelitian sebagai berikut :

Betapa banyaknya pelayanan jasa Reflexi yang menawarkan alat Reflexi di kota Malang ini, tetapi tidak optimal manfaatnya karena dirancang dengan ukuran sesuai negara asal alat tersebut, sehingga perlu penentuan ukuran Desain alat Reflexi yang disesuaikan untuk tubuh orang Indonesia (ras Asia Tenggara) dengan tujuan Penelitian dapat dibagi menjadi 3 kategori yaitu:

Tujuan Khusus yang akan dicapai dalam penelitian ini yaitu.

- Menentukan Ukuran Antrophometri Desain Alat Reflexi sesuai ukuran tubuh bangsa Indonesia

Tujuan lain yaitu :

- Membuat rasa nyaman bagi pengguna jasa Reflexi karena ukuran alat tersebut sama dengan ukuran tubuhnya.

- Hasil Reflexi akan lebih efektif karena mengenah syaraf yang akan direflexi.

Manfaat dari Penelitian ini yaitu :

a) Mendapatkan standar ukuran Desain alat Reflexi.

b) Menawarkan suatu alat yang di Desain berdasarkan standar Ergonomi.

\section{METODE}

\section{a.Metode Penelitian}

Pelaksanaan Penelitian diawali dengan pengumpulan data-data yang dibutuhkan yaitu data Anthropometri tubuh manusia yang menggunakan alat Reflexi

dengan cara pengukuran seperti pada gambar Struktur Antropometri.

Adapun data-data yang dibutuhkan yaitu :

- Data alat Reflexi yang ada di tempat Pelayanan Jasa Reflexi

- Data-data Anthropometri pasien untuk mendesain alat Reflexi

\section{b.Metode Pengolahan Data.}

- Uji Keseragaman Data dan kecukupan data dengan metode Statistik menggunakan Tingkat kepercayaan $95 \%$ dan tingkat ketelitian $5 \%$.
-Menentukan Ukuran Anthropometri untuk mendesain alat Reflexi.

\section{c.Penetapan Ukuran Anthropometri terdiri dari: \\ - Tinggi Tubuh \\ - Lebar Bahu \\ - Panjang Punggung \\ - Lebar Pinggul \\ - Lebar Pinggang \\ - Panjang popliteal}

\section{Diagram Alir Penelitian}

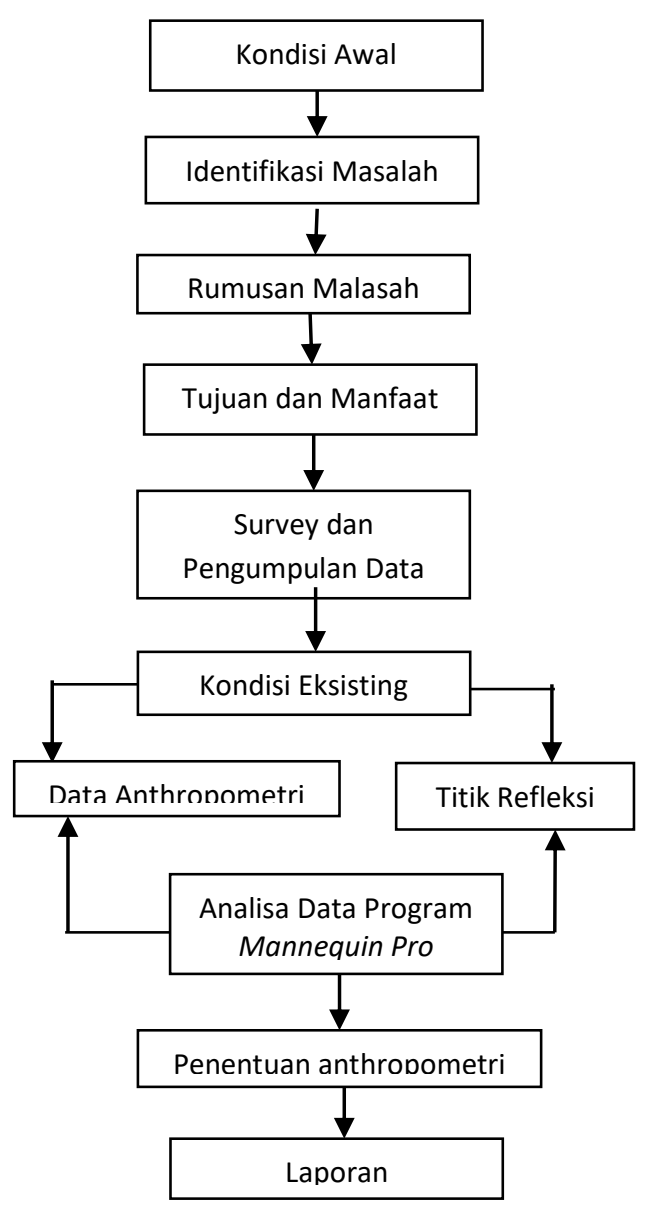




\section{HASIL DAN PEMBAHASAN}

a.Analisa Titik Terapi Tubuh pada Terapi CeragemCeragem merupakan sebutan alat kesehatan yang menggunakan teknologi sinar infra merah yang dipadukan dengan batu giok dalam balutan mesin berteknologi canggih. Khasiat Batu Giok antara lain:

- Infra merah yang terkandung didalamnya mampu mensterilkan dan menurunkan panas, sehingga mempercepat kegiatan kerja pada sistem pencernaan, sistem urinasi, sitem peredaran darah dan sistem hormon pemakainya.

- Akupresur dan moksibasi (jalur energi yang disalurkan) di sekitar tulang belakang memperbaiki metabolisme di seluruh tubuh.

- Membuang darah kotor dalam pembuluh darah.

- Memperlancar sirkulasi darah dengan moksibasi atau pemanasan pada pembuluh darah.

- Membantu semua organ tubuh, melenturkan juga melatih akar-akar saraf yang kaku.

- Meningkatkan hubungan antara tubuh dan sistem saraf ,melenturkan saraf pusat yang kencang.

- Memperbaiki tulang bengkok dan posisi tubuh bungkuk.

- Membebaskan gumpalan darah kotor di sekitar tulang dan kulit dengan cara menghancurkan gumpalan darah beku.

- Meningkatkan daya ingat dan mengurangi kepikunan dengan merangsang daerah Hypocampus, dalam hal ini Batu Giok digunakan sebagai alas kepala.

- Setiap keping batu giok dapat ditempelkan pada kulit dengan cara diplester dan biasanya dalam 5 menit ada rasa sensarai energi yanga pada masing-masing orang berbeda rasanya.

- Terdapat empat prinsip utama pengobatan ceragem yakni urut, knop, Infra merah jauh dan Chiroparactic (tulang belakang) menjadi langkah proses penyembuhan.

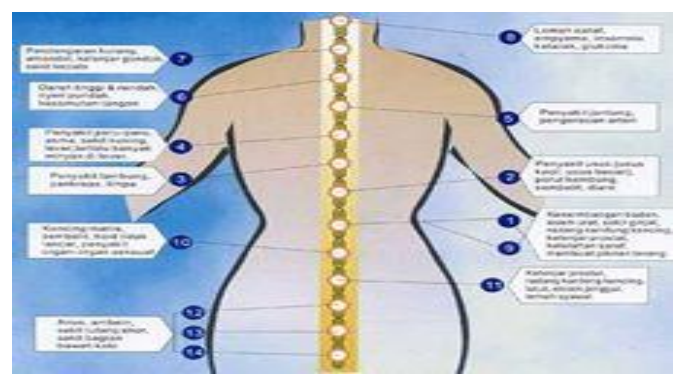

Gambar 3 Titik Terapi pada Bagian Punggung

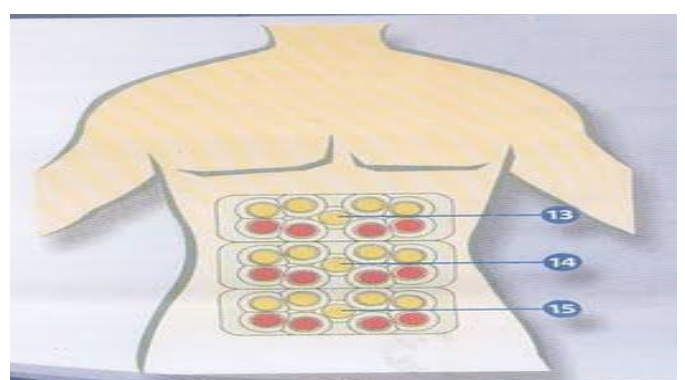

Gambar 4 :Titik Terapi pada Bagian Perut

Prinsip urut pada tubuh manusia diyakini masyarakat timur memiliki aliran chi. Apabila terserang penyakit maka aliran chi menjadi terhambat dan akibatnya metabolisme tubuh tidak berjalan normal lalu tubuh pun sakit.Dengan batu giok yang berjumlah 9 buah pada ceragem akan memberikan tekanan pada tubuh pada 12 titik di daerah tulang belakang dan 3 titik pada perut, dengan begitu aliran darah akan menjadi,lancar.Sedangkan prinsip kop, diyakini mampu memberikan rangsangan, mengaktifkan fungsi sel, membantu memproduksi sel, membersihkan pembuluh darah hingga malancarkan peredaran darah, memperbaiki syaraf dan menaktifkan metabolisme hingga tubuh anti bodi pun meningkat. Prinsip ketiga, pemberian sinar infra merah. Menurut kepercayaan masyarakat Timur, sinar infra merah merupakan sinar kehidupan yang diyakini mampu menembus ke dalam tubuh dengan mengeluarkan rasa panas dan selanjutnya mendeteksi penyakit ditubuh.

Sinar infra merah yang berpadu ketika batu giok memberikan tekanan pada titik-titik pada tubuh akan sumber penyakit. Hasil deteksi terlihat pada kulit yang menjadi kemerahan karena peredaran darah ditubuh tidak lancar.Prinsip terakhir adalah Chiropractic atau tulang belakang. Ceragem, dikatakan Ratri memang pengobatan yang menyakini bahwa sumber berbagai penyakit berasal dari tulang belakang. Tulang punggung, memiliki susunan syaraf yang vital bagi tubuh. Ketika tubuh mengalami gangguan maka diyakini permasalahan bisa berasal dari tulang belakang.

\section{b.Analisa Ergonomi}

Berdasarkan hasil pengamatan pada tempat tidur yang digunakan pada terapi batu giok dapat disimpulkan bahwa perletakkan batu giok pada tempat tidur tidak sesuai dengan perletakkan titik-titik tubuh yang akan diterapi. Hal tersebut disebabkan oleh ukuran temapat tidur yang tidak sesuai dengan ukuran 
tubuh orang Indoneisa sebagai pengguna alat terapi.

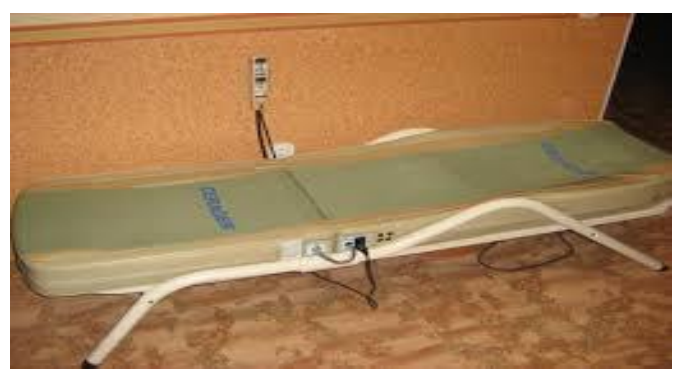

Gambar 5;Tempat Tidur untuk Terapi Batu Giok

Titik-titik terapi tubuh pasien seperti pada gambar 5.1 dan 5.2, membutuhkan perletakan dari batu giok harus disesuaikan dengan antropometri tubuh orang Indonesia. Antropometri yang digunakan untuk menentukan dimensi tempat tidur pada terapi batu giok meliputi:

a. Tinggi Tubuh

Dengan pertimbangan; Untuk menentukan panjang tempat tidur terapi yang disesuaikan dengan antropometri orang Indonesia 50 persentile, supaya dapat mengakomodir semua ukuran baik ukuran orang yang pendek maupun yang tinggi.

b. Panjang Tulang Belakang

Dengan pertimbangan:Untuk menentukan perletakkan dari batu giok yang diletakkan disekitar bagian tulang belakang, disesuaikan dengan antropometri orang Indonesia 50 persentile, supaya dapat mengakomodir semua ukuran baik ukuran orang yang pendek maupun yang tinggi.

c. Lebar Bahu

Dengan pertimbangan: Untuk menentukan lebar tempat tidur terapi yang disesuaikan dengan antropometri orang Indonesia 50 persentile, supaya dapat mengakomodir semua ukuran baik ukuran orang yang pendek maupun yang tinggi.

d. Panjang Popliteal

Untuk menentukan perletakkan dari batu giok yang diletakkan disekitar bagian betis, disesuaikan dengan antropometri orang Indonesia 50 persentile, supaya dapat mengakomodir semua ukuran baik ukuran orang yang pendek maupun yang tinggi.

e. Panjang Paha

Untuk menentukan perletakkan dari batu giok yang diletakkan disekitar bagian paha, disesuaikan dengan antropometri orang Indonesia 50 persentile, supaya dapat mengakomodir semua ukuran baik ukuran orang yang pendek maupun yang tinggi.

f. Panjang Perut

Untuk menentukan perletakkan dari batu giok yang diletakkan disekitar bagian perut, disesuaikan dengan antropometri orang Indonesia 50 persentile, supaya dapat mengakomodir semua ukuran baik ukuran orang yang pendek maupun yang tinggi.

g. Lebar Pinggul

Untuk menentukan perletakkan dari batu giok yang diletakkan disekitar bagian pinggang dan pinggul, disesuaikan dengan antropometri orang Indonesia 50 persentile, supaya dapat mengakomodir semua ukuran baik ukuran orang yang pendek maupun yang tinggi.

\section{Perhitungan Antropometri}

Tabel 4 ;Hasil Pengukuran Antropometri

\begin{tabular}{|c|l|c|}
\hline No & \multicolumn{1}{|c|}{$\begin{array}{c}\text { Jenis } \\
\text { Antropometri }\end{array}$} & $\begin{array}{c}\text { Ukuran } \\
\text { (satuan cm) }\end{array}$ \\
\hline 1 & Tinggi tubuh & 170 \\
\hline 2 & $\begin{array}{l}\text { Panang Tulang } \\
\text { Belakang }\end{array}$ & 72 \\
\hline 3 & Lebar Bahu & 52 \\
\hline 4 & Panjang Popliteal & 45 \\
\hline 5 & Panjang Paha & 55 \\
\hline 6 & Panjang Perut & 26 \\
\hline 7 & Lebar Pinggul & 41 \\
\hline
\end{tabular}

Tabel 5. Distribusi Frekuensi Tinggi Badan

\begin{tabular}{|c|c|c|c|}
\hline $\begin{array}{c}\text { Kelas } \\
\text { Interval }\end{array}$ & Frekuensi & $\begin{array}{c}\text { Frekuensi } \\
\text { Komulasi }\end{array}$ & $\begin{array}{c}\text { Frek. } \\
\text { Kom. } \\
\text { Relative } \\
(\%)\end{array}$ \\
\hline $160-161$ & 5 & 5 & 16.67 \\
\hline $162-163$ & 0 & 5 & 16.67 \\
\hline $164-165$ & 6 & 11 & 36.67 \\
\hline $166-167$ & 8 & 19 & 63.33 \\
\hline $168-169$ & 6 & 25 & 83.33 \\
\hline $170-$ & 5 & 30 & 100.00 \\
\hline 171 & 5 & &
\end{tabular}


Tabel 6. Hasil Pengukuran Antropometri

\begin{tabular}{|c|l|c|}
\hline No & \multicolumn{1}{|c|}{$\begin{array}{c}\text { Jenis } \\
\text { Antropometri }\end{array}$} & $\begin{array}{c}\text { Ukuran } \\
\text { (satuan cm) }\end{array}$ \\
\hline 1 & Tinggi tubuh & 170 \\
\hline 2 & $\begin{array}{l}\text { Panang Tulang } \\
\text { Belakang }\end{array}$ & 72 \\
\hline 3 & Lebar Bahu & 52 \\
\hline 4 & Panjang Popliteal & 45 \\
\hline 5 & Panjang Paha & 55 \\
\hline 6 & Panjang Perut & 26 \\
\hline 7 & Lebar Pinggul & 41 \\
\hline
\end{tabular}

\section{KESIMPULAN DAN SARAN}

\section{Kesimpulan}

Berdasarkan hasil penelitian dapat disimpulkan bahwa pada tempat tidur yang digunakan utuk terapi batu giok harus sesuai dengan perletakkan titik-titik tubuh yang akan diterapi, dalam arti harus sesuai dengan antropometri tubuh pasien ( orang Indonesia). Hal tersebut dimaksudkan supaya manfaat yang diterima oleh pasien pada saat tubuhnya diterapi mendapatkan hasil yang maksimal sehingga dapat mengurangi atau menyembuhkan penyakit yang diderita pasien. Antropometri yang dibutuhkan sebagai berikut:

- Tinggi Tubuh

Dengan pertimbangan:untuk menentukan panjang tempat tidur terapi $=170 \mathrm{~cm}$

- Panjang Tulang Belakang

Dengan pertimbangan:untuk menentukan perletakkan dari batu giok yang diletakkan disekitar bagian tulang belakang $=72 \mathrm{~cm}$

- Lebar Bahu

Dengan pertimbangan:untuk menentukan lebar tempat tidur terapi $=52 \mathrm{~cm}$

- Panjang Popliteal

Untuk menentukan perletakkan dari batu giok yang diletakkan disekitar bagian betis = $45 \mathrm{~cm}$.

- Panjang Paha

Untuk menentukan perletakkan dari batu giok yang diletakkan disekitar bagian paha $=$ $55 \mathrm{~cm}$

\section{- Panjang Perut}

Untuk menentukan perletakkan dari batu giok yang diletakkan disekitar bagian perut $=$ $26 \mathrm{~cm}$

- Lebar Pinggul

Untuk menentukan perletakkan dari batu giok yang diletakkan disekitar bagian pinggang dan pinggul $=41 \mathrm{~cm}$.

\section{Saran}

Penggunaan alat kesehatan yang langsung berhubungan dengan tubuh manusia sebagai pengguna hendaknya harus disesuaikan dengan antropometri tubuh manusia yang menggunakan. Hal ini terutama bagi peralatan kesehatan yang berkaitan dengan penyembuhan titik-titik syaraf sehingga dapat berfungsi secara efektif dan mencapai tujuan utama dari alat tersebut.

\section{DAFTAR PUSTAKA}

E., Grandjen, Fitting the Task to the Man, Taylor \& Fancis Ltd, London, 1982.

Nurmianto, Eko, 2003. Ergonomi Konsep Dasar dan Aplikasinya, Edisi kedua, Institut Teknologi Sepuluh November, Surabaya.

Suma'mur, 1987. Ergonomi untuk Produktivitas Kerja, Dharma Bhakti Muara Agung.

VITAMIND, 2002. Temukan Golden Moment Anda Panduan Praktis Bioritme, Gramedia Pustaka Utama, Jakarta.

Wignjosoebroto, Sritomo, 2000. Ergonomi Studi Gerak dan Waktu, Edisi pertama, Guna Widya, Surabaya.

\section{William Mendenhall, Statistics for} engineering and The Sciences, third edition, Universitas of South Florida. 